\title{
HIGH-RESOLUTION MAGNETOSTRATIGRAPHY OF SPELEOTHEMS FROM SNEŽNA JAMA, KAMNIK-SAVINJA ALPS, SLOVENIA
}

PODROBNA MAGNETOSTRATIGRAFSKA ANALIZA SIGE IZ SNEŽNE JAME, KAMNIŠKO-SAVINJSKE ALPE, SLOVENIJA

PAVEL BOSÁK ${ }^{1} \&$ HELENA HERCMAN ${ }^{2} \&$ ANDREJ MIHEVC $^{3} \&$ PETR PRUNER ${ }^{1}$

\footnotetext{
${ }^{1}$ Institute of Geology, Academy of Sciences of the Czech Republic, Rozvojová 135, 16502 PRAHA 6, CZECH REPUBLIC, e-mail: bosak@gli.cas.cz; pruner@gli.cas.cz

${ }^{2}$ Institute of Geological Sciences, Polish Academy of Sciences, ul. Twarda 51-55, 00-818 WARSZAWA, POLAND, e-mail: hercman@twarda.pan.pl

${ }^{3}$ Karst Research Institute ZRC SAZU, Titov trg 2, 6230 POSTOJNA, SLOVENIA, e-mail:mihevc@zrc-sazu.si
} 


\section{Pavel Bosák \& Helena Hercman \& Andrej Mihevc \& Petr Pruner: Podrobna magnetostratigrafska analiza sige iz Snežne jame, Kamniško-Savinjske alpe, Slovenija}

Snežna jama je velika vodoravna fosilna epifreatična jama. Leži v grebenu Raduhe, V delu KamniškoSavinjskih Alp v SV Sloveniji. V bližini vhoda je v jami v okrog $3 \mathrm{~m}$ visok prerezu razgaljeno zaporedje plasti sig s številnimi prekinitvami rasti in izdatno terigeno komponento v spodnjem delu. V 2,4 m dolgem zveznem profilu smo vzeli zaporedne vzorce, ki smo jih proučili z termalno demagnetizacijsko metodo in metodo spreminjajočega magnetnega polja. Magnetostratigrafske analize so pokazale 7 normalnih in 6 reverznih magnetocon. Magnetne lastnosti se dobro ujemajo z litološko mejo v profilu sige. Spodnji del profila kaže večjo magnetno susceptibilnost in močnejšo remanentno magnetizacijo. Sprememba lastnosti v profilu nakazuje pomembno paleogeografsko spremembo v času nastajanja sige. Starost sige sega izven dosega datacijske metode alfa spektrometrične analize U razpadne vrste; ravnotežje U izotopov pa nakazuje starost večjo od 1,2 Ma. Najbolj verjetna starost sige, ki jo dobimo z korelacijo s primerjavo z geomagnetno časovno skalo je bodisi 3,0 do 5,0 ali 1.8 do 3.6 Ma. Starost jame lahko primerjamo z nekaterimi brezstropimi jamami na krasu v JZ Sloveniji, kjer sedimentacijo v jamah postavljamo v mesinsko obdobje. Snežna jama je bila dvignjena v sedanjo višino z mlajšimi (plio-pleistocenskimi) dvigovanji Alpskega loka.

Ključne besede: magnetostratigrafija, datiranje U/Th , Snežna jama, Slovenija.

\section{Abstract}

UDC: 551.44(497.4)

\section{Pavel Bosák \& Helena Hercman \& Andrej Mihevc \& Petr Pruner: High-resolution magnetostratigraphy of speleothems from Snežna jama, Kamnik-Savinja Alps, Slovenia}

The Snežna jama Cave is located in the Kamnik-Savinja Alps, NE Slovenia, in a Raduha Ridge. The cave is a huge, more or less horizontal fossil phreatic/epiphreatic conduit. It is penetrated by vertical shafts - invasion vadose (proglacial) caves. Close to the cave entrance, there is about $3 \mathrm{~m}$ high wall composed of speleothems - a complex sequence of flowstone with numerous breaks in deposition, six of them are principal. The lower part of the profile (about $85 \mathrm{~cm}$ ) contains abundant terrigenous component (terra rossa-derived clay). Stalagmites developed in several periods are completely buried by nearly horizontal younger sequences of flowstone. Continuous speleothem log was recovered from the profile in a total length of about $2.4 \mathrm{~m}$. The rock column was cut to cubes in the laboratory $(2 \times 2 \times 2 \mathrm{~cm})$ and studied both by thermal demagnetisation ( 23 samples, 12 steps - 20 to $620^{\circ} \mathrm{C}$ ) and alternating field method ( 98 samples, 14 steps - 1 to $100 \mathrm{mT}$ ). Magnetic properties identified the lithological boundary. In contrast to the upper part, the lower one shows both higher magnetic susceptibility and higher remanent magnetisation. The turn point can indicate important palaeogeographical change. Magnetostratigraphic log is composed of 7 normal and 6 reverse polarised magnetozones. The age of speleothems detected by the U-series alpha-counting spectrometry falls outside the method range, i.e. over $350 \mathrm{ka}$. Uranium isotopic equilibria indicate the age over 1.2 Ma. The age of the fill is pre-Quaternary, clearly older than $1.77 \mathrm{Ma}$. The most probable age from correlation with geomagnetic polarity timescales is about 3.0 to 5.0 or 1.8 to $3.6 \mathrm{Ma}$. Both possibilities can indicate the growth rate of speleothems of about 1.1 to $1.3 \mathrm{~m}$ per $1 \mathrm{Ma}$. The age of speleogenesis can be compared to some of unroofed caves in the area of the Classical Karst (SW Slovenia) connected with the Messinian period. Snežna jama was uplifted to high altitudes by younger (Plio-Pleistocene) uplift of the Alpine chain.

Key words: magnetostratigraphy, U-series dating, Snežna Cave, Slovenia. 


\section{INTRODUCTION}

Snežna jama in the Kamnik-Savinja Alps (Raduha Massif, NE Slovenia) represents a highly important site from the point of view of cave evolution in Slovenia. The huge, nearly horizontal cave at a substantial altitude represents, without any doubt, a relict of an ancient karstification related to a completely different arrangement of morphology of the Slovenian Alps.

The first reconnaissance trip was carried out in June 1999 to check the availability of profiles for palaeomagnetic analysis. It was discovered that visible near-surface fine-grained siliciclastic sediments are too disturbed by post-sedimentary processes (especially frost-driven slope movements) to be suitable for detection of their palaeomagnetic properties. More, the available profile was too shallow. However, it cannot be excluded that after the digging of small shaft, sediments will be less disturbed in the depth. On the other hand, the sequence of spelothems having substantial thickness was discovered in the entrance hall of the cave. Prof. Stein-Erik Lauritzen (University of Bergen, Norway) took a hand sample of the speleothem for U-series dating, which later showed the age over the limit of the method (i.e. $>350 \mathrm{ka}$ ).

The sampling of the speleothem profile was carried out on November 8 and 9, 2001 by A. Mihevc, P. Pruner and P. Bosák. The continuous column of spelothem was recovered; it was divided to samples for detailed palaeomagnetic analysis, for dating by $U$-series $\alpha$-spectrometric method and for stable isotope analyses. The preliminary interpretation of palaeomagnetic analyses (especially alternating field demagnetisation) and U-series dating is presented in this contribution.

Palaeomagnetism of speleothems has been used to test for normality or reversal where a sample is known to be older than $350 \mathrm{ka}\left({ }^{230} \mathrm{Th} /{ }^{234} \mathrm{U}\right.$ method) or older than about $1.5 \mathrm{Ma}$ $\left({ }^{234} \mathrm{U} /{ }^{238} \mathrm{U}\right.$ method), and to obtain dated, high-resolution curves of recent secular variations (Ford $\&$ Williams, 1989). In spite of very low magnetic intensities, speleothems can carry natural remanent magnetism either as a chemical precipitate (CRM) or as floodwater or filtrate detrital grains (DRM). Carrier of magnetism is mostly magnetite. Latham et al. (1979) published the first data for speleothems from Canada and Great Britain. Reversed magnetic signature in speleothem was detected by Latham et al. (1982) in British Columbia and by Šroubek \& Diehl (1995) in Moravian Karst. Latham et al. $(1986,1987)$ studied secular variation on stalagmites from Mexico and Canada obtaining good secular variation curves and evidences for a drift. Martin (1991) detected palaeoinclination changes in last 4-20 ka for stalagmite and flowstone in Gardner Cave (Washington, USA). Brooks et al. and D.C. Ford (in Hill, 1987) applied palaeomagnetic analysis to speleothems form the Carlsbad Cavens.

Palaeomagnetic analyses were completed in the Laboratory of Palaeomagnetics of the Institute of Geology of the Academy of Sciences of the Czech Republic in Praha-Prühonice (Petr Pruner and the lab staff). U-series dating was carried out in the Uranium-Thorium Laboratory of the Institute of Geological Sciences, Polish Academy of Sciences in Warsaw (Helena Hercman and the lab staff).

\section{SITE LOCATION AND CHARACTERISTIC}

The Raduha Massif is the eastern carbonate promontory of the Kamnik-Savinja Alps. Deeply entrenched valleys separate it from other mountain ridges, i.e. the Savinja River and its tributaries 


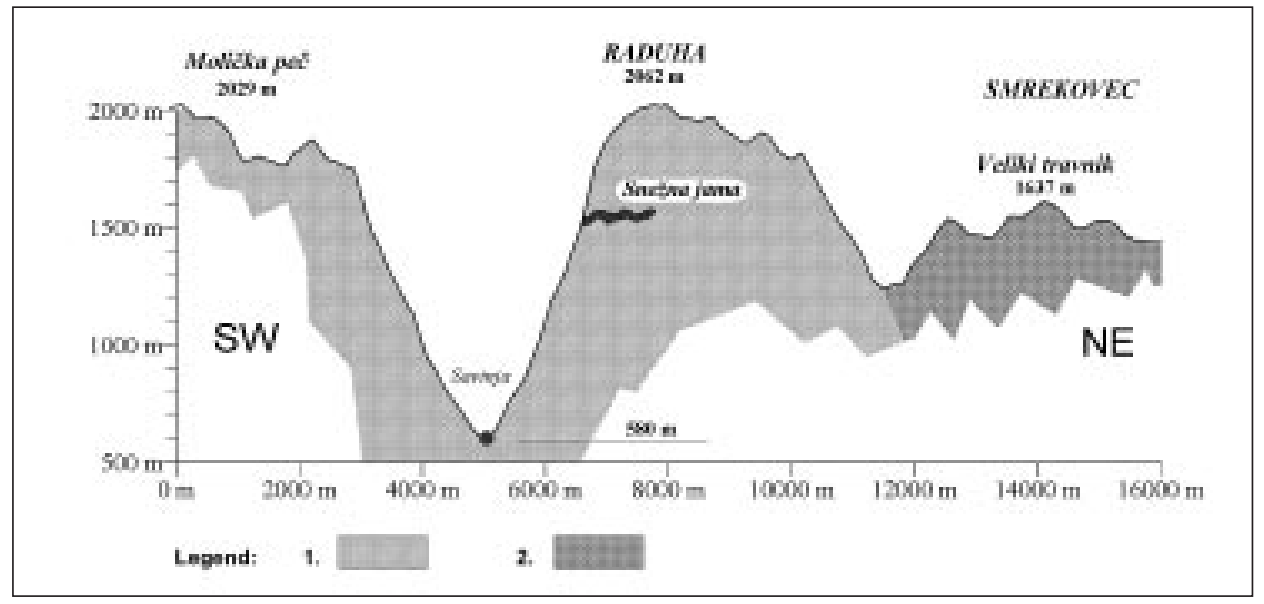

Fig. 1: Schematic cross-section of the Raduha Massif with the position of the Snežna jama. 1. limestone, 2. noncarbonate rocks.

from the Kamnik-Savinja Alps on the west, tributaries of the Meža River from the Karavanke Ridge on the north, and less distinctive valley of the Lakovnikov potok Creek from the Smrekovec Mountain on the east. The Raduha Massif is about $8 \mathrm{~km}$ long carbonate ridge overlying noncarbonate basement. Steep slopes are developed on the southern and eastern side. The northern side consists of several hundred metres high walls.

The ridge of the Raduha is an uplifted block of massive and thick-bedded upper Triassic limestone. North of Raduha, there are Lower Triassic sandstones, shales and thin bedded limestones (Fig. 1). Upper Oligocene andesitic tuffs and tuffites on the east constitute the Smrekovec Mountain. After Oligocene, strong tectonic activity along the Periadriatic lineament north of Raduha caused dextral slip faulting, folding and tilting of beds as well as general and differential uplifting. (Fodor et al. 1998; Mioč 1997). This provoked strong erosion in some areas, and Oligocene cover on the Triassic sequences was removed.

There are several caves, mostly deep shafts in the massif. The Snežna jama (Snow Cave) is the largest one. The waters that sink into the karst of Raduha reappear in karst springs in the Savinja Valley at about $580 \mathrm{~m}$ a.s.l. (Fig. 1).

\section{THE CAVE}

The cave of Snežna jama is $160 \mathrm{~m}$ long horizontal cave at altitude between 1500 and $1600 \mathrm{~m}$ a.s.l. (Fig. 1). It is situated to the south of the highest summit of the Raduha Ridge (Velika Raduha, 2062 m a.s.l.), about $900 \mathrm{~m}$ above the bottom of the Savinja Valley (Naraglav \& Ramšak, 1990). The entrance is opened in the southwestern slope of the mountain. The collapse terminates the cave close to the vertical northern edge of the Raduha Massif.

The main part of the cave consists of a large mostly horizontal gallery, which is penetrated by four large invasion vadose shafts. In one of them, the cave entrance is developed. Shafts represent 
an important feature as strong airflow brings cold into the cave. Therefore, permanent ice can appear and last in the entrance part of the cave.

The principal part of the cave was formed in phreatic and epiphreatic conditions. Fluvial sediments and large flowstone masses were deposited in the main gallery of the cave. In one part of the gallery representing a sump with paragenetic features, more than $10 \mathrm{~m}$ high profile of fluvial sediments is preserved. Deposits consist of laminated clays and sands with well-rounded pebbles up to $30 \mathrm{~mm}$ in size. Allochthonous pebbles mostly composed of andesite tuffs and tuffites prevail, while poorly-rounded autochthonous limestone pebbles are less frequent. Allochthonous deposits possibly came from the Smrekovec Mountain east of the Raduha. At the present time, contact of volcanic and volcaniclastic rocks with limestones lies1 km southeast of the cave, but at altitude of $350 \mathrm{~m}$ below it (Fig. 1).

In the main gallery of the cave, large flowstone masses were deposited over older sediments. Speleothems, large flowstone domes and massive stalagmites, covered nearly the whole surface. Massive flowstone was deposited also in some of vadose shafts; it was later corroded away, leaving some traces only. There is no deposition of flowstone at present climatic conditions in the cave and in other caves at the same altitude. This kind of flowstone and its abundance can be compared only with caves recently at altitudes below $500 \mathrm{~m}$ a.s.l. in the Mediterranean area. Flowstone is damaged by frost activity in the entrance part of the cave. Speleothems were broken away and moved by cryoturbation. The influence of frost and cryogenic damage of speleothems and cave walls can be seen within the whole cave with actual average annual temperature of about $4.5^{\circ} \mathrm{C}$. Speleothems are missing at the terminal part of the cave, where the gallery was interrupted by an extensive collapse. A skeleton of Ursus speleaeus was found here. The cave bear could not enter the cave trough the recent entrance, so there had to be another entrance in the terminal part of the cave.

\section{DESCRIPTION OF PROFILE}

The speleothem profile is situated in the inner part of the Ledena dvorana (The Ice Chamber) about $90 \mathrm{~m}$ from the entrance to the cave at the depth of about $45 \mathrm{~m}$ (Fig. 2).

Speleothems are developed as a complex sequence of flowstone with numerous breaks in deposition, six of them are principal. The lower part of the profile contains abundant terrigenous component (most probably clay of terra rossa-type). Stalagmites developed in several periods are completely buried by nearly horizontal younger sequences of flowstone. Some stalagmites were buried even broken. Approximately $2.4 \mathrm{~m}$ of flowstone were sampled continuously in three successive profiles (1) (2) (3) on Fig. 3). Profile No. 3 was situated in a basal part of the sequence (4 to $52 \mathrm{~cm})$. Profile No. 2 was situated in the lower part of the sequence $(42$ to $85 \mathrm{~cm})$ terminating on important unconformity plane within speleothems and overlapping $10 \mathrm{~cm}$ with the previous profile. Profile No. 3 was composed of three individual sections in the middle and upper parts of the sequence with sectors from 85 to $123 \mathrm{~cm}, 123$ to 201 and 201 to $222 \mathrm{~cm}$. Above the main wall, there were situated several layers of speleothems representing the top of the sequence at 222 to $238 \mathrm{~cm}$, which is not expressed on the drawing on Figure 3).

The description of the profile is based on continuous column of speleothem recovered by sampling, from bottom to top. 


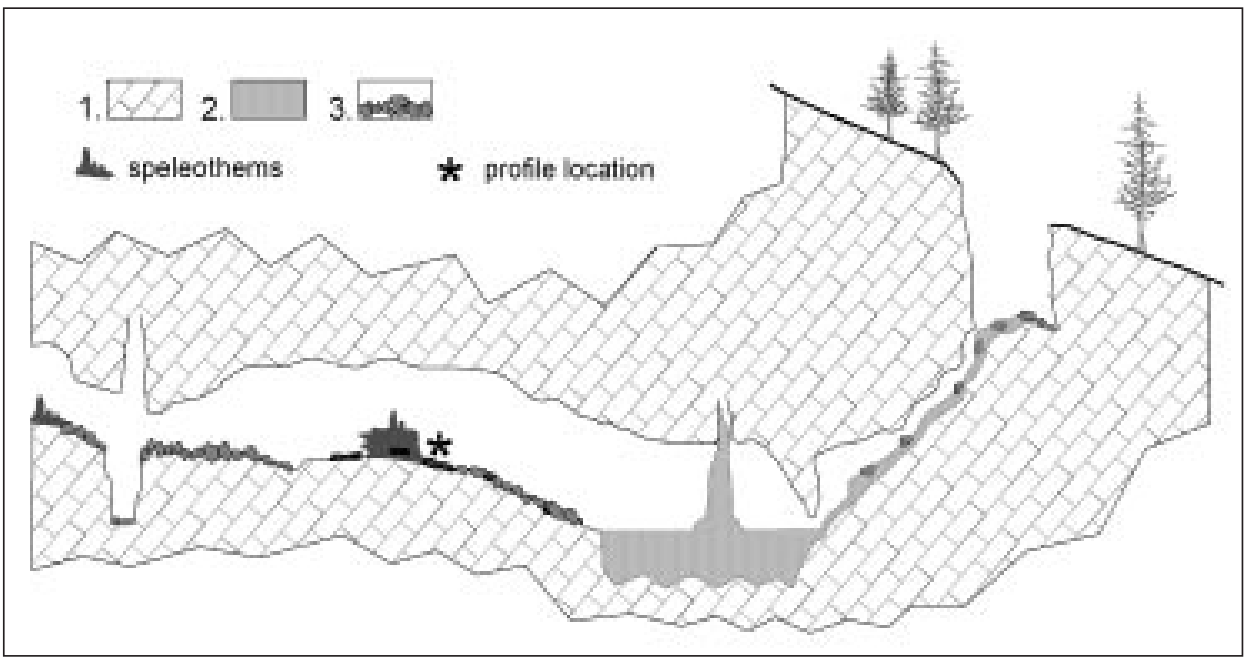

Fig. 2: Cross section of the entrance part of the Snežna jama na Raduhi with the position of the profile studied. 1. limestone, 2. cave ice, 3. rubble.

\section{$4-13 \mathrm{~cm}$ (profile (3))}

speleothem, fine-crystalline, porous, vuggy, light brown, reddish at base, fine-crystalline coatings on vug walls.

\section{3-31 cm (profile (3)}

speleothem, fine-crystalline, porous, fenestral, light brown with reddish laminae and bands, flat fenestral vugs, bands differ in size and abundance of vugs, top $3 \mathrm{~cm}$ without vugs, finecrystalline coatings on vug walls and 1-2 mm thick palisade coating of white calcite on walls of larger vugs.

\section{$31-46 \mathrm{~cm}$ (profile (3))}

speleothem, fine-crystalline, porous, vuggy, light brown, greyish at top, greyish bands, finecrystalline coatings on vug walls.

$46-52 \mathrm{~cm}$ (profile (3)

speleothem, fine-crystalline, alternation of porous and massive bands, porous in bands, vuggy, light brown, reddish bands, fine-crystalline coatings on vug walls.

$40-49 \mathrm{~cm}$ (profile (2)

speleothem, alternation of fenestral and more massive bands, grey to light brown, reddish, blistering fine-crystalline coatings on vug walls

$49-52 \mathrm{~cm}$ (profile (2)

speleothem, banded, alternation of fenestral and massive bands, grey to light brown, reddish, blistering fine-crystalline coatings on vug walls

$52-62 \mathrm{~cm}$ (profile (2)

speleothem, banded, alternation of fenestral and massive bands, light brown, reddish, alternation of reddish massive bands with brown more fenestral ones, in general more massive, corrosional vugs, blistering fine-crystalline coatings on vug walls. 


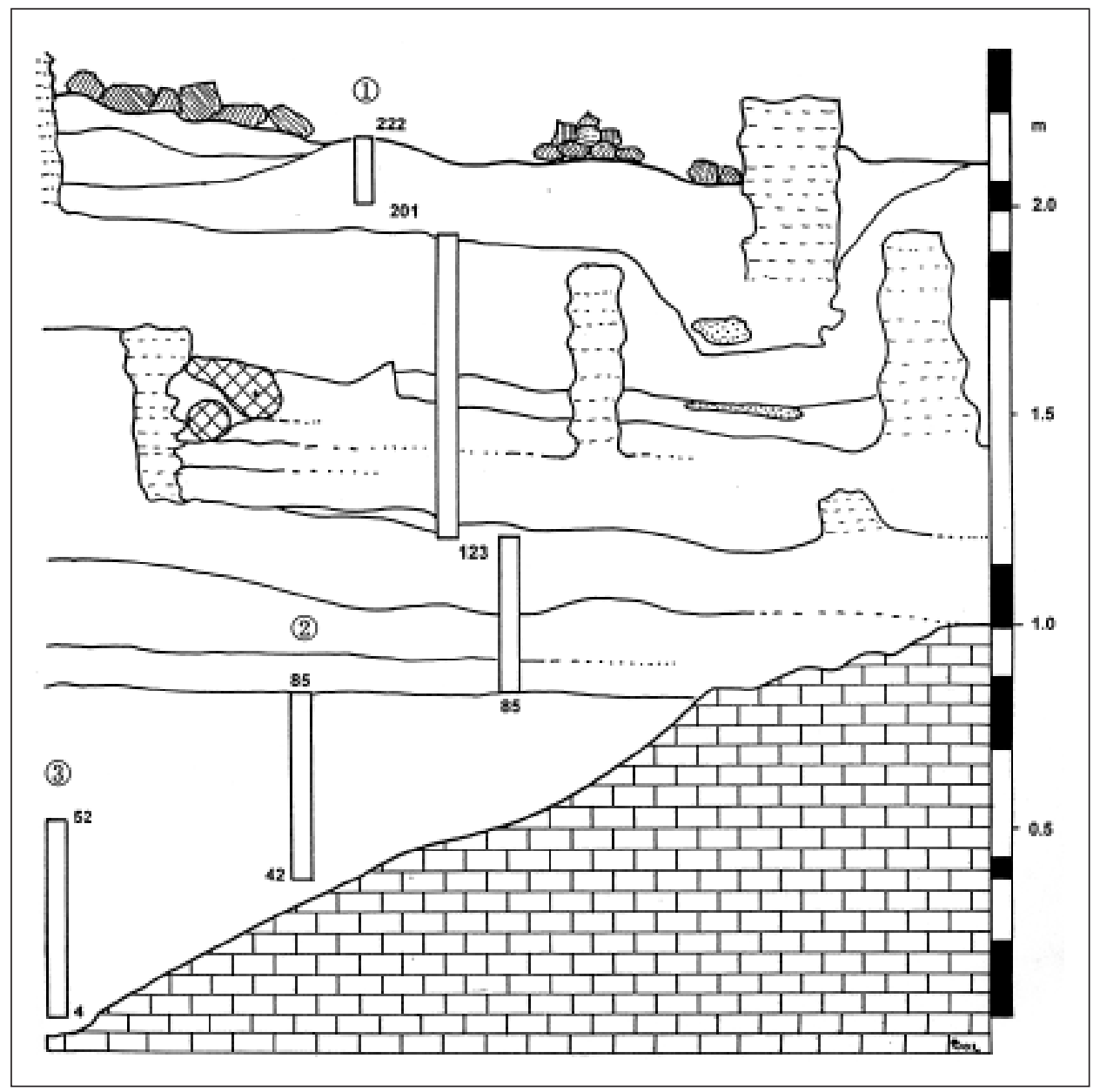

Fig. 3: Snežna jama, schematic sketch of the flowstone profile (stalagmites - dashed, broken stalagmites - cross shading, cavities - dotted; (1) to (3) - sampling profiles, numbers refer to the height in cm above the profile base; magnetostratigraphy log on the right side: white - reverse magnetic polarity, black - normal magnetic polarity).

\section{2-85 cm (profile (2))}

speleothem, banded, alternation of fenestral and massive bands, grey to light brown, reddish, in lower part with alternation of reddish massive bands with fenestral brown bands, in upper part more brownish grey to dark beige bands, more porous, corrosional vugs, blistering fine-crystalline coatings on vug walls.

$88-103 \mathrm{~cm}$ (profile (1)/1)

speleothems, laminated to banded, alternation of reddish and beige to white thin bands, lightcoloured bands are composed of columnar calcite crystals (recrystallised). 


\section{3-107 cm (profile (1)/1)}

speleothems, laminated in bands, light brown to dark beige, long columnar calcite crystals (recrystallised).

\section{7-115 cm (profile (1)/1)}

speleothem, laminated, light ochreous and light greyish white, beige laminae (1-2 mm thick). $115-139 \mathrm{~cm}$ (profile (1)/1+(1)/2)

speleothems, laminated in bands, yellowish white, with individual darker laminae.

$139-145 \mathrm{~cm}$ (profile (1)/2)

speleothem, laminated, alternation of laminated bands, bands with columnar structure and highly porous bands, light brown with rosy laminae (laminated and columnar bands) and light orange (porous), porous bands resemble lithified moonmilk layers.

$145 \mathrm{~cm}$ (profile (1)/2)

sand, fine-grained, clayey-silty to sandy silt, light brown.

$145-158 \mathrm{~cm}$ (profile (1)/2)

speleothem, laminated to banded, light brown, alternation of $0.5-2 \mathrm{~cm}$ bands of laminated massive and porous speleothem, porous bands have lighter colour.

$158-166 \mathrm{~cm}$ (profile (1)/2)

speleothem, banded, light brown, brown, beige, light-coloured bands are often porous, at the base and at the top with laminae of chalky appearance.

$166-176 \mathrm{~cm}$ (profile (1)/2)

speleothem, honey-coloured, darker, columnar, corroded, pseudooolithic at base (corroded, 2 $\mathrm{cm})$.

$176-188 \mathrm{~cm}$ (profile (1)/2)

speleothem, banded, honey-coloured, columnar, fine-grained beige bands $4 \mathrm{~cm}$ at the base, at $183 \mathrm{~cm}$ hedgehog crystal aggregates ( filled vugs of gours).

$188-198 \mathrm{~cm}$ (profile (1)/2)

speleothem, laminated, banded, light brown to brown, beige, alternation of columnar bands with fine-crystalline ones, with abundant corrosional vugs (up to $2 \mathrm{~cm}$ in size) with fine hedgehog-like wall coatings.

198-202 cm (profile (1)/2)

speleothem, laminated, light brown, red and beige laminae, with light grey bands, which are more massive but finely-porous, dessication cracks(?) at the base.

202-209 cm (profile (1)/3)

speleothem, irregularly laminated, porous, light brown, rosy laminae at top.

209-222 cm (profile (1)/3)

speleothems, banded, brown, light brown, beige, porous, corroded.

222-229 cm (profile (1)/top)

speleothem, banded, beige, light brown, alternation of thicker columnar beige bands and thin laminated light brown bands, corroded at the base, dessication cracks at the base (unconformity). 229-238 cm (profile (1)/top)

speleothem, banded $(2-3 \mathrm{~cm})$, beige, light brown, alternation of thicker columnar beige bands and thin laminated light brown bands, highly porous - corroded. 


\section{PALAEOMAGNETIC AND PETROMAGNETIC MEASUREMENTS}

\section{Method of sampling and preparation of laboratory samples}

The sampling was carried out using the engine-powered saw. Parallel cuts $(4-5 \mathrm{~cm}$ in distance) were produced and column of rock was removed by chisel and hammer. This unique sampling method, applied for sampling in caves for the first time, enabled us to obtain the continuous sample and to minimise the impact of sampling on the profile. The short distance from the entrance and the meteorology of the ice cave caused exhalations from engine and some dust produced during rock cutting to be transported by warmer air immediately and directly out of the cave through the steeply inclined entrance cave passage.

The column of speleothem was cut in the laboratory to oriented cubes $(2 \times 2 \times 2 \mathrm{~cm})$. The rest of the sample was processed as specimen for $\mathrm{Th} / \mathrm{U}$ dating and stable isotope analysis $(\mathrm{O}, \mathrm{C})$.

In totall 100 samples were prepared (i.e. after each $2.5 \mathrm{~cm}$ ) for palaeomagnetic and magnetostratigraphic analysis, making the profile the most detailed examined by palaeomagnetic method in Slovenia.

\section{Laboratory procedures}

Laboratory procedures was based on progressive demagnetisation by alternating field (AF) or thermal demagnetisation (TD) to detect components of remanent magnetic polarity in different intervals and to determine moduli and directions of remanent magnetisation.

Oriented hand samples were collected in the cave and processed in the laboratory. In the laboratory, they were measured on the JR-5 spinner magnetometer (Jelínek, 1966). All 98 specimens were demagnetised by the alternating field procedures, up to a field of 1,000 Oe in 14 steps. The LDA apparatus was employed for the AF demagnetisation. Selected 23 specimens will be thermally demagnetised using the MAVACS (Magnetic Vacuum Control System) apparatus securing generation of a high magnetic vacuum (Príhoda et al., 1989).

The remanent magnetisation of specimens in their natural state (NRM) is identified by the symbol $J_{\mathrm{n}}$, the corresponding remanent magnetic moment by the symbol M. Graphs of normalised values of $M / M_{0}=F(H, t)$ were constructed for each analysed specimen.

The volume magnetic susceptibility $\left(k_{\mathrm{n}}\right)$ was measured on a KLY-2 kappa-bridge (Jelínek, 1973). Separation of the respective remanent magnetisation components was carried out by multicomponent Kirschvink analysis (Kirschvink, 1980). The statistics of Fisher (1953) were employed for calculation of mean directions of the pertinent remanence components derived by the multicomponent analysis.

\section{Palaeomagnetic and petromagnetic results}

Results of the AF demagnetisation are presented here. Values of the moduli of natural remanent magnetisation $J_{\mathrm{n}}$ and those of magnetic susceptibility $k_{\mathrm{n}}$ of the studied rocks in their natural state show a big scatter. The mean values of moduli of natural remanent magnetisation $J_{\mathrm{n}}$ and of magnetic susceptibility $k_{\mathrm{n}}$ from 98 samples are documented in Table 1 . According values of both moduli in samples, the profile may be divided into two parts. From 33 samples of the lower part of the profile $(7-83 \mathrm{~cm})$, the mean values of both moduli are $J_{\mathrm{n}}=197.1 \pm 121.8\left[\mathrm{~mA} \cdot \mathrm{m}^{-1}\right]$ and $k_{\mathrm{n}}=207.8 \pm 44.5 \times 10^{-6}[\mathrm{SI}]$. This group of samples is characterised by intermediate values of $J_{\mathrm{n}}$ and of $k_{\mathrm{n}}$ The mean values of moduli from 65 samples of the upper part of the profile $(83-238 \mathrm{~cm})$ 
are $J_{\mathrm{n}}=6.1 \pm 19.3\left[\mathrm{~mA} \cdot \mathrm{m}^{-1}\right]$ and $k_{\mathrm{n}}=-2.6 \pm 12.0 \times 10^{-6}[\mathrm{SI}]$. Samples from the upper part are characterised by extremaly low values of $J_{\mathrm{n}}$ and $k_{\mathrm{n}}$.

Directions of remanent magnetisation inferred by the above given procedures were tested using a multi-component analysis. A-components of remanence are mostly of viscous or chemoremanent (weathering) origin; they can be removed by an alternating field with the intensity of 1 up to $5 \mathrm{mT}$. Normal and reverse $C$-component directions $\left(\mathrm{D}_{\mathrm{p}}, \mathrm{I}_{\mathrm{p}}\right.$ - declination and inclination) of the samples are documented on Figure 4. The Fisherian distribution forms two welldefined sets of samples with normal and reverse polarities.

Palaeomagnetic and magnetostratigraphic investigations carried out on 98 oriented laboratory specimens provided data concerning principal magnetic properties and identification of palaeomagnetic directions. Magnetostratigraphic results of samples from this profile show nor-

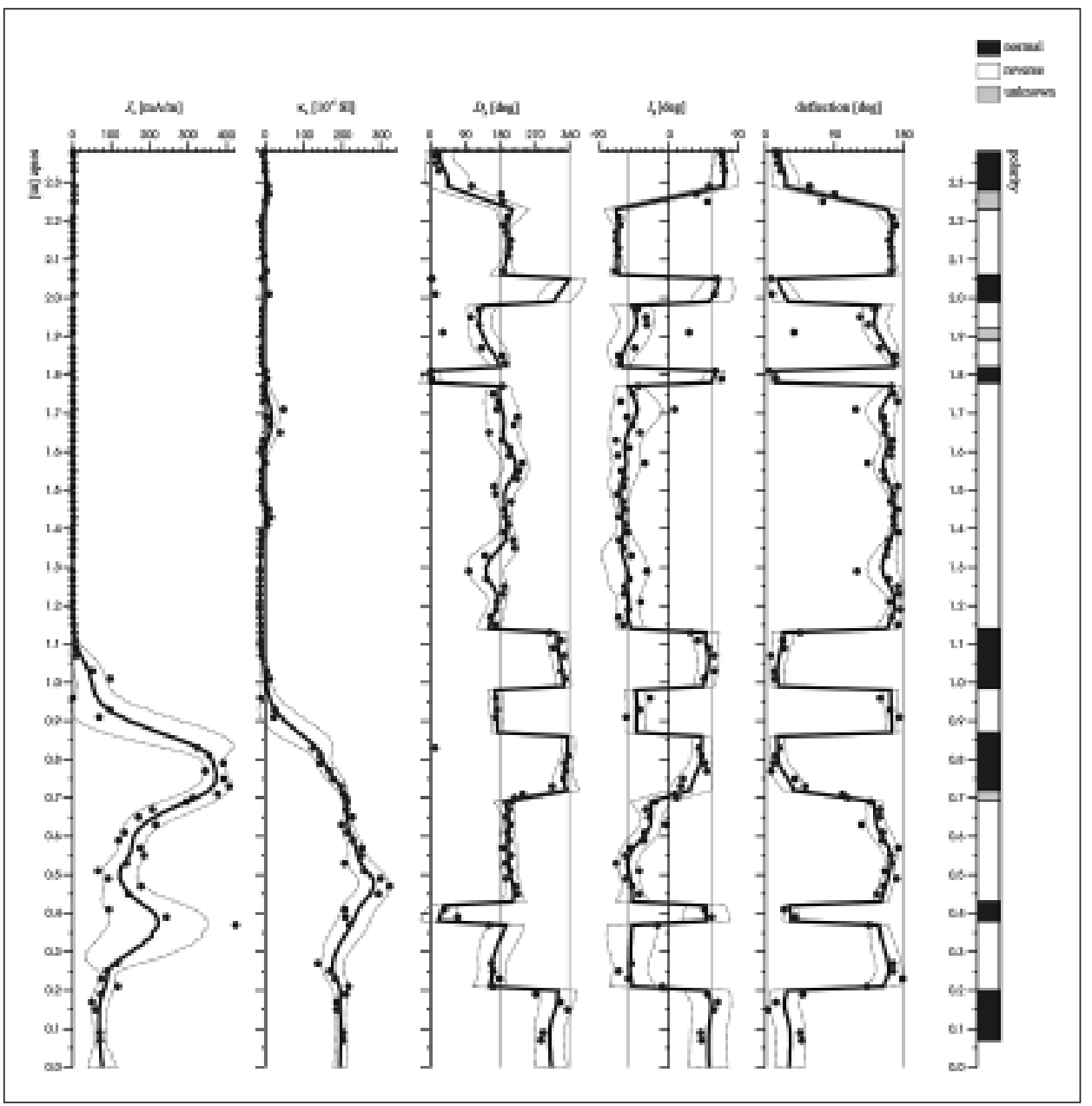

Fig. 4: Basic magnetic and magnetostratigraphic parameters. 
mal and reverse polarity magnetozones. The top of the profile shows normal magnetozone (from 227 to $238 \mathrm{~cm})$. Two narrow normal magnetozones $(201-205 \mathrm{~cm}$ and $179-182 \mathrm{~cm}$ ) are documented in the long reverse zone (from 115 to $225 \mathrm{~cm}$ ). Middle and lower parts of the profile from 7 to $113 \mathrm{~cm}$ show two narrow $(91-96 \mathrm{~cm}, 21-37 \mathrm{~cm})$ and one longer $(45-70 \mathrm{~cm})$ reverse polarity zones.

Table 1: Mean value and standard deviation of natural remanent magnetisation and volume magnetic susceptibility.

\begin{tabular}{|l|c|c|c|}
\hline & $\begin{array}{c}\mathrm{J}_{\mathrm{n}} \\
{\left[\mathrm{mA} \cdot \mathrm{m}^{-1}\right]}\end{array}$ & $\begin{array}{c}\mathrm{k}_{\mathrm{n}} \times 10^{-6} \\
{[\mathrm{SI}]}\end{array}$ & 207.8 \\
\hline Mean value & 197.1 & 44.5 & Interval [m] \\
\hline Standard deviation & 121.8 & 33 & $0.07-0.83$ \\
\hline Number of samples & 33 & -2.6 & Interval [m] \\
\hline Mean value & 6.1 & 12.0 & $0.83-2.38$ \\
\hline Standard deviation & 19.3 & 65 & \\
\hline Number of samples & 65 & & \\
\hline
\end{tabular}

\section{U-SERIES DATING}

Standard chemical procedure for uranium and thorium separation from carbonate samples was used (Ivanovich \& Harmon, 1992). Activities measurements were performed using OCTETE PC made by EG\&G ORTEC ( $\alpha$-spectrometry method). Spectra analyses and age calculations have been done using "URANOTHOR 2.5" software, which is standard software, used in USeries Laboratory in Warsaw (Gorka \& Hercman, 2002). The quoted errors are one standard deviation.

All samples are characterised by low U content. As a result accuracy of analyses are rather low. Additionally significant contamination by detrital thorium is visible in samples W809 and W806 $\left({ }^{230} \mathrm{Th} /{ }^{232} \mathrm{Th}<20\right)$.

${ }^{230} \mathrm{Th} /{ }^{234} \mathrm{U}$ activity ratios are in equilibrium in the error range (1 standard deviation). We can assumed that measured value is different then any other (equilibrium value $=1$ in our situation) if the difference is minimum 2 standard deviations. Taking account this rule we have no evidence to tell that there is disequilibrium between ${ }^{230} \mathrm{Th}$ and ${ }^{234} \mathrm{U}$ in uranium series basing on our measurement results.

Minimum age border estimation seems to be, in this situation, the safest solution. Minimum age borders have been estimated basing on measured activities ratios and their accuracy (measured activity ratios minus error). Corrected minimum age borders take account detrital contamination and have been estimated assuming initial ${ }^{230} \mathrm{Th} /{ }^{232} \mathrm{Th}$ activity ratio in detritus equal $1.5 \pm 0.5$.

${ }^{234} \mathrm{U} /{ }^{238} \mathrm{U}$ activity ratios, except the samples with significant detrital contamination, are in equilibrium in the error range. It may suggest the age $>1.2 \mathrm{Ma}$. This conclusion needs caution because low accuracy of activity ratios. Any other proof is needed. 
For the samples with significant detrital contamination we should take account that not only Th, but $U$ as well, may be mobilised at the time of dissolution of sample. At the time of uranium mobilisation enrichment of ${ }^{234} U$ is characteristic. Higher values of ${ }^{234} U /{ }^{238} U$ activity ratios in the samples with significant detrital contamination may suggest that not only Thorium but also uranium contamination must be assumed for these samples. It means that results of U-series dating for these samples are not reliable.

Table 2: U-series dating results using $\alpha$-spectrometry.

\begin{tabular}{|c|c|c|c|c|c|c|c|}
\hline $\begin{array}{c}\text { Sample } \\
{[\mathrm{cm}]}\end{array}$ & Lab. No. & $\begin{array}{l}\text { U conc. } \\
\text { [ppm] }\end{array}$ & ${ }^{234} \mathrm{U} /{ }^{238} \mathrm{U}$ & ${ }^{230} \mathrm{Th} /{ }^{34} \mathrm{U}$ & ${ }^{230} \mathrm{Th} /{ }^{232} \mathrm{Th}$ & $\begin{array}{c}\text { Min. age* } \\
{[\mathrm{ka}]}\end{array}$ & Remarks \\
\hline 117 & W 813 & $0.037 \pm 0.019$ & $1.087 \pm 0.555$ & $0.976 \pm 0.108$ & 23 & $>300$ & \\
\hline 121 & W 809 & $0.052 \pm 0.009$ & $1.142 \pm 0.190$ & $1.042 \pm 0.071$ & 10 & & $\begin{array}{l}\text { Significant detrital } \\
\text { contamination }\end{array}$ \\
\hline 125 & W 810 & $0.057 \pm 0.006$ & $1.063 \pm 0.106$ & $0.969 \pm 0.051$ & 60 & $>300$ & \\
\hline 129 & W 814 & $0.040 \pm 0.010$ & $0.994 \pm 0.239$ & $0.913 \pm 0.104$ & 40 & $>200$ & \\
\hline 131 & W 811 & $0.070 \pm 0.010$ & $0.971 \pm 0.144$ & $0.987 \pm 0.064$ & 72 & $>300$ & \\
\hline 147 & W 806 & $0.031 \pm 0.007$ & $1.403 \pm 0.323$ & $0.926 \pm 0.072$ & 6 & & $\begin{array}{c}\text { Significant detrital } \\
\text { contamination }\end{array}$ \\
\hline
\end{tabular}

* Minimum age calculated basing on activity ratios and their accuracy

\section{DISCUSSION}

Complex magnetostratigraphic picture was obtained by high-resolution palaeomagnetic analysis. Dense sampling contributed to the precision of detection of individual subchron boundaries. Totally 7 normal polarised zones are separated by 6 reverse polarised zones. According to U-series dating, both by S.-E. Lauritzen (pers. comm., 2000) and our analyses, all studied samples are older than 350 or $200 \mathrm{ka}$. Uranium isotopic equilibria indicate the substantial age of samples, clearly over 1.2 Ma. The correlation with the standard geomagnetic polarity time scales (GPTS) for Cenozoic (Cande \& Kent, 1995) is highly risky especially owing several unconformities within the profile, which can hide substantial time periods (cf. Bosák et al., 2000b). Some of detected magnetozones terminate or start on such unconformities $(85,201$ and $222 \mathrm{~cm})$. Some unconformites are expressed by the stalagmite growth on them. The height of stalagmites (about $50 \mathrm{~cm}$ ) can indicate that the time necessary for the growth of each of them did not exceeded several $10^{1} \mathrm{ka}$.

It can be expected, that the profile represents time sequence not younger than Matuyama chron (1.77 Ma, Olduvai subchron). The profile can be rather correlated with Gauss and Gilbert chrons (about 2.6 to $5 \mathrm{Ma}$ ). The geometry of individual magnetozones and their arrangement, taking into account also hidden time on unconformities, indicates the most probable correlation with subchrons at 3.0 to $5.0 \mathrm{Ma}$; another probable correlation could be 1.8 to $3.6 \mathrm{Ma}$. Both possibilities indicate the growth time of speleothems for an approximately equal time 
(1.8 to $2.0 \mathrm{Ma}$ ), which can indicate the speleothem growth rate of about 1.1 to1.3 $\mathrm{m}$ per $1 \mathrm{Ma}$.

The distribution of natural remanent magnetisation (NRM, $\left.J_{\mathrm{n}}\right)$ and total magnetic susceptibility $\left(k_{\mathrm{n}}\right)$ indicates the composition of the sequence from two units (Fig. 4). The lower part of the profile has substantially higher NRM values $\left(J_{n}\right.$ from 0.05 to $\left.0.5 \mathrm{~A} \cdot \mathrm{m}^{-1}\right)$. The unit is composed of banded brown speleothem with high content of terrigenous-derived material resembling reworked and redeposited terra rossa-like soil. The upper part, above approx. $103 \mathrm{~cm}$, composed of typical light-coloured banded flowstone sequence, shows negligible NRM values reaching max. $4 \mathrm{~mA} \cdot \mathrm{m}^{-1}$. The total magnetic susceptibility curve indicates similar trend. The interpretation of NRM and $\kappa$ curves is highly problematic without final stable isotope curve. If the $\kappa$ curve represents the reflection not only of the iron content in terrigenous influx to the cave, but also the climatic conditions ( $c f$. e.g., Sroubek et al. 2001), then we can expect the different palaeoenvironmental conditions during evolution of both parts of the profile. The more detailed evaluation will be possible only after stable isotope analyses will be available.

Very rough reconstruction of the cave development can be deduced both from the cave morphology and fills and our preliminary results. The main part of the cave was formed as phreatic/ epiphreatic cave containing watertable elements with only some vadose remodelation connected mostly with bypassing (e.g., paragenesis). The subterranean flow had an estimated recharge of several cubic metres per second. Both the dimensions and shape of the main cave gallery indicate the stabilisation of piezometric level for a prolonged time period. According to pebble composition, the catchment area was situated to the southeast of the cave on the Upper Oligocene volcanogenic rocks. The altitude differences of the relief at the time of cave formation can be estimated as $600 \mathrm{~m}$ at least, but the hydraulic head in the karst was small.

Pebbles of Miocene rocks were found in the Potočka zijalka Cave (Mihevc, 2001) at similar altitude about $10 \mathrm{~km}$ to the north of the Raduha. It cannot be excluded that both caves were formed in the same prolonged stable period during Upper Miocene and Pliocene.

Fluvial sediment deposited in the Snežna jama were covered by thick speleothems, indicating warm, wet climate and low altitude of the cave. Flowstone, which can be compared with low altitude circum-Mediterranean appearance, was deposited in different climatic conditions and/or before the main uplift of the mountain. The deposition of speleothems ceased due to climate change caused by the mountain uplift and/or some other general reasons (climate cycles).

Fast mountain uplift caused, that surface rivers entrenched and cut subterranean karst drainage. The fall of the piezometric level for about $900 \mathrm{~m}$ created conditions favourable for vertical drainage and origin of invasion vadose shafts most probably connected with melt of glaciers (proglacial caves sensu Głazek, Rudnicki \& Szynkiewicz, 1977). Karst drainage was reorganised and cave finally remained dry (fossilised) and has faced very little change. Some vertical shafts simply penetrate the cave leaving the main passage unchanged, which is comparable with other high mountainous areas, e.g., the Northern Limestone Alps in Austria (Bauer \& Zötl, 1972; Zötl, 1989), Western Tatra Mts. In Poland (Kicińska, 2002), Karzhantau Ridge in southern Kazakhstan (Bosák et al., 1985; Bosák, 1989).

The morphological conditions of the Kamnik-Savinja Alps are comparable with another part of the Alpine chain - the Northern Calcareous Alps. Already Schauberger (1956) discussed the concentration of caves at certain elevations for the Tennengebirge, the Dachstein Massif and the Totes Gebirge. Zötl (1989) reported that main cave systems in the Dachstein area are situated at 
1300 to $1500 \mathrm{~m}$ a.s.l., i.e. $900 \mathrm{~m}$ above the erosion base. Also caves in the Hegengebirge and the Hochschwab Massif are concentrated at 1300 to $1700 \mathrm{~m}$ a.s.l., and 1400 to $1600 \mathrm{~m}$ a.s.l., respectively.

In upper Pleistocene, the denudation of the slopes reached the cave and probably creates two entrances. The cave bear could enter the cave through yet unknown one on the northwesten side of the ridge. Cold Pleistocene climate or simply two entrances with strong air circulation caused the freezing of the whole cave. Recently these processes are limited only to the entrance part where the subterranean glacier exists. Frost processes destroyed and moved thick layers of speleothems.

The time of fossilisation of the Snežna jama can be compared with some of other palaeomagnetically investigated caves in Slovenia, especially with unroofed caves uncovered in the Classical Karst (SW Slovenia). Magnetostratigraphic data from the Divača profile (Bosák, Pruner \& Zupan Hajna, 1998), Kozina profile (Bosák et al., 2000a), Černotiče I (Bosák et al., 1999) and Černotiče II (Bosák, Pruner \& Mihevc, 2002) indicate that the age of all those cave fills is older than 1.77 Ma with possible ages from about 2.6/3.8 to about 5.23 Ma matching obtained magnetostratigraphy logs with the GPSR for Cenozoic (Cande \& Kent, 1995). Although recently occurring in completely different altitudes, the host caves can represent the result of the same speleogenetical epoch connected with the Messinian period (Bosák et al., 1998). In the Northern Calcareous Alps, the main phase of subterranean flow connected with the last stage of origin of huge horizontal cave systems is expected in Pliocene (see fig. 4-2 in Zötl, 1989). The difference of altitudes can be easily attributed to the later uplift of Alpine mountain chain during Pliocene-Quaternary, which separated hydrologically karst massifs from the respective catchment areas. This palaleogeographic change is well-recorded in palaeomagnetic properties of speleothems in the Snežna jama.

\section{CONCLUSIONS}

A nearly $2.5 \mathrm{~m}$ high profile of banded and laminated flowstone with buried stalagmites was studied in a relic phreatic/epiphreatic tunnel-shaped cave at high altitude (Kamnik-Savinja Alps, Raduha Massif). The lower part of the profile consisted of vuggy and banded reddish and brownish coloured speleothems (up to about $85 \mathrm{~cm}$ ). The upper part was composed of light-coloured laminated flowstones. The profiles contained about 6 principal surfaces of unconformities. The $\mathrm{Th} / \mathrm{U}$ dating clearly proved the age above the limit of method (i.e. $>350 \mathrm{ka}$ ) and isotopic ratios indicated age over 1.2 Ma.

In all 100 samples were prepared from the continuously sampled log. The alternating field demagnetisation was finished on 98 samples. According values of both moduli in samples, the profile may be divided into two parts and categories. From 33 samples of the lower part of the profile $(7-83 \mathrm{~cm})$, the mean values of both moduli are $J_{\mathrm{n}}=197.1 \pm 121.8\left[\mathrm{~mA} \cdot \mathrm{m}^{-1}\right]$ and $k_{\mathrm{n}}=207.8 \pm 44.5 \times 10^{-6}[\mathrm{SI}]$. This group of samples is characterised by intermediate values of $J_{\mathrm{n}}$ and of $k_{\mathrm{n}}$ The mean values of moduli from 66 samples of the upper part of the profile $(83-238 \mathrm{~cm})$ are $J_{\mathrm{n}}=6.1 \pm 19.3\left[\mathrm{~mA} \cdot \mathrm{m}^{-1}\right]$ and $k_{\mathrm{n}}=-2.6 \pm 12.0 \times 10^{-6}[\mathrm{SI}]$. Samples from the upper part are characterised by very low values of $J_{\mathrm{n}}$ and $k_{\mathrm{n}}$. 
Magnetostratigraphic results of samples from this profile show normal and reverse polarity magnetozones. The top of the profile shows narrow normal magnetozone (from 227 to $238 \mathrm{~cm}$ ). Two very narrow normal magnetozones $(201-205 \mathrm{~cm}$ and $179-182 \mathrm{~cm})$ are documented in the long reverse zone $(115-225 \mathrm{~cm})$. Middle and lower parts of the profile from 7 to $113 \mathrm{~cm}$ show two narrow $(91-96 \mathrm{~cm}, 21-37 \mathrm{~cm})$ and one longer $(45-70 \mathrm{~cm})$ reverse polarity zones.

The distribution of natural remanent magnetisation (NRM, $J_{\mathrm{n}}$ ) and bulk magnetic susceptibility $\left(k_{\mathrm{n}}\right)$ indicates the composition of the sequence from two entirely differing units. The lower part has substantially higher NRM values. The upper part, above approx. $103 \mathrm{~cm}$, composed of typical light-coloured banded flowstone sequence, shows negligible NRM values. The bulk magnetic susceptibility curve indicates similar trends. The change of depositional environment between 85 and $103 \mathrm{~cm}$ of the profile represents the important turn point in the evolution of the cave, i.e. the gradual decrease in influx of terrigenous material from the surface. It seems highly probable, that this interval marks the start of entrenchment of valley system by the start of more accelerated uplift of mountains in that part of Kamnik-Savinja Alps, which resulted in the detachment of subterranean river system from its catchment area and fossilisation of the cave.

The age of the fill is pre-Quaternary, clearly older than 1.2 Ma (U-series data) and $1.77 \mathrm{Ma}$ (magnetostratigraphy interpretation). The most probable correlation is about 3.0 to 5.0 or 1.8 to 3.6 Ma. Both possibilities indicate the time of speleothem origin within about 1.8 and $2.0 \mathrm{Ma}$, which can indicate the growth rate of speleothems of about 1.1 to $1.3 \mathrm{~m}$ per $1 \mathrm{Ma}$. The cave is a result of the same speleogenetical epoch (Messinian) as some of caves in the low-altitude Classical Karst (Divača profile, Kozina profile, Černotiče) being uplifted by younger (Plio-Pleistocene) uplift of the Alpine chain, which represents the identical evolution as cave systems of the Northern Calcareous Alps in Austria.

\section{ACKNOWLEDGEMENT}

We would like to thank to darko Naraglav and Silvo Ramšak and Jamarsko društvo Črni galeb, Prebold for their help during the sampling of the sediments. Palaeomagnetic analyses were performed by Mrs. Dr. Daniela Venhodová, software for evaluation of measurements was prepared by Dr. Ota Man, and samples for palaeomagnetic analyses were cut by Mr. Jiř́ Petráček (Department of Palaeomagnetism, Institute of Geology ASCR, Praha-Průhonice). Travel costs were covered within the frame of the program KONTAKT 2001-2003 of the Czech Ministry of Education, Youth and Sports and Slovenian Ministry of Education, Sport and Science. Expenses of analytical procedures were covered from sources of the Program of Advancements in Scientific Research in Key Directions of the Academy of Sciences of the Czech Republic No. K1-042-603 and grant project of the Grant Agency of the Academy of Sciences of the Czech Republic No. A3013201: Magnetomineralogical and magnetostratigraphic research of cave and fluvial deposits in Central Europe. The study is a result of Research Plan of the Institute of Geology AS $\breve{C} R$ No. CEZ: A09198 Z3-013-912. Work of the Karst research institute ZRC SAZU was done in the frame of the program P0-0507 and project J6-3035-0618-0, both financed by the Slovenian Ministry of Education, Sport and Science. 


\section{REFERENCES}

Bauer F. \& Zötl J. 1972: Karst of Austria. - In: M. Herak \& V.T. Stringfield, Eds: Karst. Important Karst Regions of the Northern Hemisphere, 225-265, Elsevier. Amsterdam.

Bosák P. 1989: Mountainous karst of the Karzhantau Ridge (southern Kazakhstan, USSR): Phenomena and Development. - Problemy kompleksnogo izuchenia karsta gornykh stran. Sbor. Mater. mezhd. Simp. speleologov, SSSR, Tbilisi-Cchaltubo-Suchumi, 5-12.X.1987, 99-102, Mecniereba. Tbilisi.

Bosák P., Horáček I., Sýkora J. \& Tůma S. 1985: Karst phenomena of the Karzhantau Ridge (western Tchien-Shan, southern Kazakhstan; in Czech). - Čs. kras, 36, 85-96. Praha.

Bosák P., Knez M., Otrubová D., Pruner P., Slabe T. \& Venhodová D. 2000a: Palaeomagnetic Research of Fossil Cave in the Highway Construction at Kozina, SW Slovenia. - Acta Carsol., 29, 2, 1: 15-33. Ljubljana.

Bosák P., Mihevc A., Pruner P., Melka K., Venhodová D. \& Langrová A. 1999: Cave fill in the Črnotiče Quarry, SW Slovenia: Palaeomagnetic, mineralogical and geochemical study. Acta Carsol., 28/2, 2: 15-39. Ljubljana.

Bosák P., Pruner P. \& Mihevc A. 2002: Palaeomagnetic research of fill of selected caves in Slovenia. Progress Report No. 5 (Černotiče, Snežna jama). - MS, Unpubl. Rep. Inst. Geol. AS CR, 150 pp. Praha.

Bosák P., Pruner P., Mihevc A. \& Zupan Hajna N. 2000b: Magnetostratigraphy and unconformities in cave sediments: case study from the Classical Karst, SW Slovenia. - Geologos, 5, 13-30. Poznań.

Bosák P., Pruner P. \& Zupan Hajna N. 1998: Paleomagnetic research of cave sediments in SW Slovenia. - Acta Carsol., XXVII/2, 3: 151-179. Ljubljana.

Cande S.C. \& Kent D.V. 1995: Revised calibration of the geomagnetic polarity timescale for the Late Cretaceous and Cenozoic. - J. geophys. Res., 100, B4, 6093-6095.

Fisher R. 1953: Dispersion on a sphere. - Proc. Royal Soc., A 217, 295-305. London.

Fodor L., Jelen B., Márton E., Skaberne D., Čar J. \& Vrabec M. 1998: Miocene-Pliocene tectonic evolution of the Slovenian Periadriatic fault: Implications for Alpine-Carpathian extrusion models. - Tectonics, 17, 5, 690-709.

Ford D.C. \& Williams P.W. 1989: Karst geomorphology and hydrology. - Unwin Hyman, 601 pp. London.

Gams I. 1998: Kras. - In: I. Gams \& I. Vrišer, Eds.: Geografija Slovenije, Slovenska Matica, 72 pp. Ljubljana

Głazek J., Rudnicki J. \& Szynkiewicz A. 1977: Progacial caves - a special genetic type of caves in glaciated areas. - Proc. $7^{\text {th }}$ Int. Congr. Speleol., 215-217. Sheffield.

Gorka P. \& Hercman H. 2002: URANOTHOR v. 2.5. Delphi Code of calculation program and user guide. - MS, Arch. Quarter. Geol. Dept., Inst. Geol. Sci., PAS. Warsaw.

Hill, C.A., 1987: Geology of Carlsbad Cavern and other caves in the Guadelupe Mountains, New Mexico and Texas. - New Mexico Bureau Mines Miner. Resources Bull., 117, 1-152.

Ivanovich M. \& Harmon R.S., Eds. 1992: Uranium series disequilibrium. Applications to environmental problems. $2^{\text {nd }} \mathrm{Ed}$. - Clarendon, $910 \mathrm{pp}$. Oxford.

Jelínek V. 1966: A high sensitivity spinner magnetometer. - Stud. Geophys. Geodaet., 10, 58-78. Praha. 
Jelínek V. 1973: Precision A.C. bridge set for measuring magnetic susceptibility and its anisotropy. - Stud. Geophys. Geodaet., 17, 36-48. Praha.

Kicińska D. 2002: Cenozoic evolution of karstwater circulation in Western Tatras Mts. - MS, $\mathrm{PhD}$. Thesis, 104 pp. A. Mickiewicz Univ. Poznań.

Kirschvink J. L. 1980: The least-squares line and plane and the analysis of palaeomagnetic data. Geophys. J. Royal Astronom. Soc., 62, 699-718. Oxford.

Latham A., Schwarcz H.P. \& Ford D.C. 1979: Palaeomagnetism of stalagmite deposits. -Nature, 280, 5721, 383-385.

Latham A., Schwarcz H.P. \& Ford D.C. 1986: The paleomagnetism and U-Th dating of Mexican stalagmite, DAS2. - Earth Planet. Sci. Letters, 79, 195-2047.

Latham A., Schwarcz H.P. \& Ford D.C. 1987: Secular variations of the Earth's magnetic field from 18.5 to $15.0 \mathrm{ka}$ B.P., as recorded in a Vancouver Island stalagmite. - Canad. J. Earth Sci., 24, 1235-1241.

Martin K. 1991: Paleomagnetism of speleothems in Gardner Cave, Washington. - Natl. Speleol. Soc. Bull., 52, 2(1990), 87-94.

Mihevc A. 2001: Jamski fluvialni sedimenti v Snežni jami na Raduhi in v Potočki zijalki. - 15. Posvetovanje slovenskih geologov: povzetki referatov, Geološki zbornik, 16, 60-63. Ljubljana

Mioč P. 1997: Tectonic Structures Along the Periadriatic Lineament in Slovenia. - Geologia Croatica, 50, 2, 251-260. Zagreb

Naraglav D. \& Ramsak S. 1990: Snežna jama na Raduhi. - Naše jame, 32, 88-92. Ljubljana

Př́ihoda K., Krs M., Pešina B. \& Bláha J. 1989: MAVACS - a new system of creating a nonmagnetic environment for palaeomagnetic studies. - Cuad. Geol. Ibérica, 12, 223-250. Madrid.

Schauberger O. 1956: Über die vertikale Verteilung der alpinen Karsthöhlen - Mitt. Höhlenkomm. (Wien), 1 (1955), 21-28.

Šroubek P. \& Diehl J.F. 1995: The paleoenvironmental implications of the study of rock magnetism in cave sediments of the Moravian Karst. - Knih. Čes. speleol. Spol., 25, 29-30. Praha.

Sroubek P., Diehl J.F., Kadlec J. \& Valoch K. 2001: A Late Pleistocene paleoclimate record based on mineral magnetic properties of the entrance facies sediments of Kulna Cave, Czech Republic. - Geophys. J. Int., 147, 247-262.

Zötl J. 1989: Paleokarst as an important hydrogeological factor. - In: P Bosák., D.C. Ford, J. Głazek \& I. Horáček, Eds: Paleokarst. A systematic and regional review, 483-509, Academia-Elsevier. Praha-Amsterdam.

\section{PODROBNA MAGNETOSTRATIGRAFSKA ANALIZA SIGE IZ SNEŽNE JAME, KAMNIŠKO-SAVINJSKE ALPE, SLOVENIJA}

\section{Povzetek}

Proučili smo skoraj 2,5 m visok profil plastovite sige s stalagmiti v Snežni jami. Jama je ostanek stare, skoraj vodoravne freatične oziroma epifreatične jame, ki leži v grebenu Raduhe, v nadmorski višini $1600 \mathrm{~m}$. Spodnji del profila sige je iz porozne in laminirane rdečkaste ali rjavkasto 
obarvane sige (skupna debelina $85 \mathrm{~cm}$ ). Zgornji del profila so sestavljale svetlejše sige. V profilu je bilo 6 pomembnih prekinitev sedimentacije. Datacija sige s pomočjo Th/U metode je jasno pokazala, da je starost sige večja kot je doseg metode (>350 Ka), razmerja U izotopov pa starost večja od 1,2 Ma.

Iz stratigrafskega stolpca sedimenta smo pripravili 100 vzorcev. Demagnetitzacija v izmeničnem magnetnem polju je bila narejena na 98 vzorcih. Izmerjene vrednosti kažejo, da lahko profil razdelimo na dva dela. Srednje vrednosti modulov 33 vzorcev iz spodnjega dela profila $(7-83 \mathrm{~cm})$ so $J_{\mathrm{n}}=197,1 \pm 121,8\left[\mathrm{~mA} \cdot \mathrm{m}^{-1}\right]$ in $k_{\mathrm{n}}=207,8 \pm 44,5 \times 10^{-6}[\mathrm{SI}]$. Za to skupino vzorcev so značilne srednje vrednost $J_{\mathrm{n}}$ in $k_{\mathrm{n}}$. Srednje vrednosti modulov 66 vzorcev iz zgornjega dela profila $(83-238 \mathrm{~cm})$ pa so $J_{\mathrm{n}}=6.1 \pm 19.3\left[\mathrm{~mA} \cdot \mathrm{m}^{-1}\right]$ in $k_{\mathrm{n}}=-2.6 \pm 12.0 \times 10^{-6}[\mathrm{SI}]$. Značilno za vzorce iz zgornjega dela profila so zelo nizke vrednosti $J_{\mathrm{n}}$ in $k_{\mathrm{n}}$.

Magnetostratigrafske analize vzorcev profila kažejo normalne in inverzne magnetne cone. Vrhnji del profila pripada ozki normalni magnetni cona (od 227-238 cm). Dve zelo ozki magnetni coni $(201-205 \mathrm{~cm}$ in $179-182 \mathrm{~cm})$ sta v dolgi inverzni magnetoconi $(115-225 \mathrm{~cm})$. Srednji in spodnji deli profila od 7 do $13 \mathrm{~cm}$ kažejo dve ozki $(91-96 \mathrm{~cm}, 21-37 \mathrm{~cm})$ in eno daljšo $(45-70 \mathrm{~cm})$ inverzno magnetno cono.

Tudi razporeditev naravne remanentne magnetnosti (NRM, $J_{n}$ ) in obseg magnetne susceptibilnosti $\left(k_{\mathrm{n}}\right)$ kaže na sestavo profila iz dveh popolnoma različnih enot. Spodnji del ima občutno višje NMR vrednosti. Zgornji del profila, nad $103 \mathrm{~cm}$, je sestavljen iz svetlejše sige in ima zanemarljive vrednosti NRM.

Krivulja magnetne susceptibilnosti kaže enak trend. Sprememba sedimentacijskih pogojev med 85 in $103 \mathrm{~cm}$ je pomembna v evoluciji celotne jame. Pomeni postopno zmanjšanje dotoka terigenih delcev s površja. Zdi se zelo verjetno, da je to povzročilo pospešeno dvigovanje KamniškoSavinjskih Alp. To je namreč povzročilo vrezovanja rečnih dolin, kar je prekinilo povezavo jame s ponikalnico in začetek fosilizacije jame.

Starost sige je pred kvartarna, zagotovo pa starejša kot 1,2 Ma (datiranje z U razpadno vrsto) in več kot 1,77 Ma (magnetostratigrafska interpretacija). Najbolj verjetna starost sige, ki jo dobimo s primerjavo z geomagnetno časovno skalo je bodisi od 3,0 do 5,0 ali od 1.8 do 3.6 Ma. Jama je nastala v podobnih speleogenetskih pogojih (verjetno v mesinskem obdobju) kot nekatere, danes že razgaljene jame na veliko nižjem klasičnem krasu (profil Divača, profil Kozina, jame v kamnolomu Črnotiče) nato pa je bila dvignjena v sedanjo višino zaradi mlajšega (pliopleistocenskega) dviga Alpskega loka. Tak razvoj jame je podoben razvoju jamskih sistemov v Severnih apneniških Alpah. 